SAD / JSR

Sosyoloji Araştırmaları Dergisi / Journal of Sociological Research

Cilt / Volume 21 Say1 / Number 1 (Nisan / April 2018) : (131-168)

\title{
THE EFFECTS OF ADOPTION OF NEW TECHNOLOGY ON THE EMPLOYMENT OF YOUNG APPRENTICES: THE CASE OF FURNITURE SECTOR IN SITELER, ANKARA
}

\section{Emek Barış KEPENEK ${ }^{1}$}

\begin{abstract}
The aim of this paper is to discuss how the technological developments implemented in the production processes and organizational structures of micro and small sized enterprises (MSEs) affect the employment process of youth in these enterprises. Furniture sector is selected as a case.

The transformations of production processes and changes in the organizational structure in small firms cause removal of young workers from the production processes.

The research was implemented in Siteler which is one of the biggest production region of Turkey. Policy recommendations to improve the quality employment processes of youngsters and furniture sector is also provided.
\end{abstract}

Keywords: Youth Employment, Technology, Deskilling

${ }^{1}$ Dr. Öğr. Üyesi, Başkent Üniversitesi Fen - Edebiyat Fakültesi, Sosyoloji Bölümü 


\section{YENİ TEKNOLOJİ UYGULAMALARININ GENÇ ÇIRAKLARIN ISTIHDAMLARINA ETKİSI: SİTELER MOBILYYA SEKTÖRÜ ÖRNEĞİ}

\section{ÖZ}

Makalenin amacı küçük ve orta ölçekli firmaların üreti süreçlerinde uygulanan teknolojik yenilenmenin genç istihdamı üzerindeki etkisini tartışmaktır. Araştırma için mobilya sektörü seçilmiştir.

Üretim süreçlerindeki değişikliker ya da firmanın organizasyon yapısındaki yenilikler genç işçilerin üretim süreçlerinden uzaklaştırılmalarına yol açmaktadır.

Araştırma Türkiye'nin en büyük mobilya üretim bölgelerinden biri olan Siteler'de yürütülmüştür. Analizler 1şı̆̆ında genç istihdamına ve mobilya sektörüne katkı sayılabilecek politika önerileri geliştirilmiştir.

Anahtar Kelimeler: Genç İstihdamı, Teknoloji, Vasıfsızlaştırma 


\section{INTRODUCTION}

The aim of this article is to investigate how technological developments implemented in the production processes and organizational structures of small and medium-sized enterprises affect the skilling and thus the employment process of youth in these enterprises. The furniture sector of Turkey is chosen as a specific industrial sector for this research.

In the late 20th century, there have been revolutionary developments in the information and communication technologies (ICTs); and this, in turn, has led to major transformations in the economic, social and cultural structures of the societies (Higon, 2011; Tarute\& Gatautis, 2014;). ICT are rapidly changing global production, work and business methods and trade and consumption patterns. Manochehri, Al-Esmail, and Ashrafi (2012) states that in order to benefit from ICT adoption, to deliver better services and explore new business opportunities, there should be satisfied at least three conditions:

- Certain infrastructure;

- $\quad$ Skilled ICT personnel;

- $\quad$ Budget to invest in ICT.

The adoption process requies a change in the structure of the firms where new management systems and new work organizations emerged; which in turn have also affected tremendously the working process and the workers. It is assumed that the success of those changes is closely interrelated with the technical and cognitive skills of the workers of the firm. "Skill" is the core concept of this article.

It can be stated that the skilled work force has an advantageous status in terms of wage and social rights over the low skilled ones in the firms. Thus, the low skilled workforce has been negatively influenced by these changes. To be more precise, young apprentices (between the ages of 18 and 24) in the furniture sector will be given special emphasis. 
The basic question is: "What are the impacts of the technological changes on youth employment in small scale furniture manufacturing firms?" The first two parts of this paper covers theoretical discussions: In the first part, the reasons that push small sized enterprises to make technological improvements are discussed. Besides, the interaction of the concept of skill and technology, both of which have economic and sociological dimensions, will be given a specific theoretical emphasis in the third part. The fourth and fifth parts cover methodological aspects and the analysis of field research. In the last part, the recommendations on the subject are open to discussion.

\section{ICT ADOPTION, SMALL FIRMS AND THE PROBLEM OF SKILL}

\subsection{Theoretical Framework}

Small and medium-sized enterprises (hereafter SMEs) are often considered as the main force for a country's economic growth. SME is considered as the sign of the promotion of the bottom-up development policies, namely the increasing role of local development in recent decades (Stöhr, 1990).

However, it is obvious that since the number of firms, even large corporations or SMEs, increase, the competition becomes more intense among them, which in turn may lower their profits. In order to overcome such problems, small firms can lower prices, improve the quality of their products, add new distribution channels, and/or improve their internal processes which can make their production processes to become more productive. Therefore, if the small firms will not do anything for itself, it will no longer have resources to counter the competition and will be forced to leave the market. Thus, there are many reasons which are important in the adoption of technology for the small firms. Therefore the adoption of ICT is recognized as crucial condition enabling SMEs to consider information and communication technologies as an important investment in their business to take competitive advantage of the global markets. (Ritchie and Brinley, 2005; Tarute\& Gatautis, 2014). 
The implementation of the ICT is a tool to lever the businesses to compete on a global scale by improving the efficiency in both production process and customer network. (Alam and Noor, 2009; p. 112). Therefore the adoption of ICT is recognized as a crucial aspect for SMEs enabling SMEs to take competitive advantage of the global markets in their business. SMEs have increasingly transferred and adopted ICT to their workflow. For example, personal computers, the internet, automated working machines, ecommerce... etc. Bayo-Moriones and Lera-Lopez (2007) argued that the use of ICT can improve business competitiveness and so provide numerous opportunities for SMEs to compete in larger markets.

But, is the adoption process easy to handle? Adoption does not mean to buy the machine and install into the production unit. There is a tough decision process behind that. According to MacGregor et al (1996), small business tends to avoid ICT into their business, if it is seen as complex to use. This is not surprising because SMEs always lack skills amongst workforce to use ICT (Spectrum, 1997). New technology has always created frustration if it is not something controllable. Studies reveal that the ICT adoption is positively related to firm size and workforce. Analysis of ICT effects in private sector is significant only after a thorough analysis of conditions that should be satisfied in order to successfully adopt ICT expectations towards positive impacts of ICT and characteristics of an individual company (financial, technological, personnel resources, the flexibility of structures etc.) are closely linked. In other words, the scale of the required set-up costs, including financial and human capital, combined with the lack of professional advice, delays adoption (Ritchie and Brindley, 2005).

Undoubtedly ICT has a powerful impact on the economic performance and could be characterized by a high degree of technological progress and productivity. Also, it has an important social impact. (Ritchie and Brindley, 2005; Matei \& Savulescu, 2012)The appropriate technology can help the firms to decrease the costs by improving the quality of production process and thus productivity within the firm. Moreover, it grants the firm the ability to adequately enter the market. For example, ICTs can significantly impact the 
market-oriented dimensions of products and services as well as manufacturing processes, working practices and management practices (Ritchie and Brindley, 2005).

The existing level of skill and knowledge is very influential in adoption process. Reynolds ed.all (1994) found that small business owner/managers are unlikely to adopt more sophisticated technologies if they are not familiar with the basic ones. This is because of the limited number of employees with lack of technical knowledge. On the contrary, the adoption of ICTs impacts the skilling profile in the firm as well. That's why the concept of skill is crucial in that manner. It should be understood better.

\subsection{What is Skill?}

"Skill" is a much contested notion in the debates about work, employment and management. In the postindustrial period or post-Fordist period was marked with more flexible production processes, decentralization and reduction in hierarchy, up-skilling of work force and relatively more demand for “knowledge workers” (Bell 1973, Attewell 1990; Piore and Sabel 1984; Zuboff, 1988). Contrarily, it is also argued that the recent technological changes have created more managerial control, reduced worker autonomy and caused the deskilling of the labor (Braverman, 1974, Zimbalist, 1979, Rifkin, 1996).

Tim Peterson and David Van Fleet (2004) define a skill as "the ability either to perform some specific behavioral task or the ability to perform some specific cognitive process that is functionally related to some particular task. They suggest three distinct components of skills:

(1) a domain-specific knowledge base,

(2) the means to access that knowledge, and

(3) the ability to take actions or thoughts using that knowledge to carry out a task.

$\mathrm{SAD} / \mathrm{JSR}$

Cilt / Volume 21 Say1 / Number 1 
For this article, the notion of skill is defined as the mental and physical capacity to carry out the necessary tasks. It also contains mental proficiency and physical dexterity. In other words, skill implies the prerequisites of having and accessing certain knowledge, processes, or sequences of behavior leading to a specific performance. There are different views on how skill changes in the workind processes.

\subsubsection{The Up-Skilling Thesis}

The Up-skilling Thesis assumed that the technical progress favors the employment of skilled workers (Piore and Sabel, 1984; Zuboff, 1988). Zuboff (1998) in her preliminary study on technology and work, "In the age of Smart Machine", discussed the informationalization of work processes on production and labor relations including management. Contrary to Braverman (1974) and Rifkin (1996), she admitted the positive impact of technological developments on job creation and upgrading of skill requirements. According to her, the effective use of the new information technologies demanded important changes in the workers' functions (in Vallas, 1990). The new developments tended to diminish the importance of manual power rather than intellectual skills. The information technologies have called the workers to improve their skill levels related to the level of technology used in the enterprise. All these aspects are also very much related to the managerial concerns and organizational interests. Zuboff also reminded that the upgrading in the skill level of the workers might cause a growing threat to the managerial authority (Zuboff, 1988). Although Zuboff admitted that all kinds of skills are not compatible with stimulating technology and they are more apt to be abolished during the process.

\subsubsection{Deskilling Process}

The deskilling thesis underlines that the objective conditions of the work will inevitably separate workers from the production process and will make them as if a part of the machine by the deskilling process. There would be an inevitable displacement of low skilled ones within the firms (Rifkin, 1996; Robinson, 2004). 
Because technical improvements have obviously favored the employment of more qualified workers. Replacement of unskilled labor has taken place within manufacturing and services. Labor has been displaced mainly in tasks which can be routinized (Rifkin, 1996; Glyn, 2006).

There is no doubt, the developed and eveloping economies desire high demand for skilled workers as compared to the jobs for unskilled workers (Piva and Livarelli, 2002; Manning, 2004). This includes many unskilled assembly line jobs, which are repetitive and can easily be replaced by computerized technology. It is clear that the new relations resulted in the deterioration of the general position of workers in society. Most of them lost their jobs and thus, their economic well-being in the society is lowered (Lipietz, 1997; Harvey, 1989).

There have also been shifts in the work organization or the production processes which definitely affect the conditions of low-skilled work force negatively. This condition of the low skilled work force has become dependent on the firms' strategies and for the most part, they are removed from the core of the production process and employed in very simple tasks. They tend to be kept deskilled and become an ordinary component in the management process of the firms (Braverman, 1974).

For Braverman, capitalist relations of production contains the necessity for capital to realize the potential of purchased labor power by transforming it into labor under its own control, thereby creating the basis for alienation. He mentioned two important aspects:

- The origins of management lay in the struggle to devise the most effective means of imposing employers' will within a new social relation of production different in kind and scope to what had existed before.

- A division of labor based on a systematic subdivision of work, rather than simple distribution of crafts, is generalized only within the capitalist mode of production. The separation of work into 
constituent elements reflects the necessary principle for the capital of dividing the craft to cheapen the parts, providing the basis for the subsequent destruction of all-round skills.

\subsubsection{The Social Construction of Skill}

In more sociological context, it is often discussed that the notion of skill is mainly constructed in social relations (Wood, 1989). Especially, the tendencies on discussions on the concept of skill have varied from technical dimension to managerial dimensions or from more economic contents, such as the source of productivity in a production process, to social relations between the employer and the employee. That is to say, the construction of skill is not the only result of objective processes; but also the result of social relations between the managers/capitalists and laborers who are dependent on them in terms of living (Rigby and Sanchis, 2006).

Although the concept of skill can be considered as the combination of knowledge and experience, it is not just a matter that can be constructed through some processes such as education and training. It is somehow related with the laborer him/herself; with his/her intention, values or other humane aspects. But, what is interesting for us is how it creates a relationship with capitalists/ managers and the laborer him/herself.

In small firms, the relations are much more personal and more dependent on the employer. It is well known that the collectivity is less strong and laborers can be subjected to more informal applications in the market which mean less social and economic rights for them. In such a situation, the social construction of skill is more likely provided by the employers.

To sum up, the problem of skill formation in an enterprise cannot be solely reduced to technical dimensions. The social condition of the employees - as it is in the women discussion - and also the political and economic relation in a society, in general, are also effective (Rigby and Sanchis, 2006). 


\subsubsection{Human Capital Theory}

Human Capital Theory (HCT) is an economic theory that enhances the importance of education as an economic growth and development device. Education and training are considered as the key factors for the workers and nations to participate in the new global economy more effectively. Since the power of knowledge has been acknowledged in recent years in the policy issues, the importance of education and thus, the skill in workplaces has gained special importance. It is emphasized that the overall economic performance of societies is more directly based on their knowledge stock and learning capabilities (Foray and Lundvall, 1996). HCT looks for the ways to raise the skill levels by additional investment in education, training and employment schemes and so on.

Human capital can be labeled as the stock of knowledge, skills, and abilities, which can help increase productivity and performance in life especially in work. According to this definition, human capital can be at the same time a goal/target for individual well-being and a means of achieving more fundamental and more long-term goals at work or in the lifetime career. In the human capital theory, it is a means of achieving higher productivity and thereby higher wages (Hietala, 2005). Human capital does not automatically increase productivity. There must be enough demand for the knowledge, skills, and abilities in the labor market and, in addition, there must be enough motivation to utilize them.

\subsubsection{Skill-Biased Technical Change}

The debates on increasing inequality on wages, rights, and status in the workplace has often been attributed to the theory of skill-biased technical change (hereafter, SBTC) after the 1990s. This theory argues that SBTC is a shift in the production technology that favors skilled labor over the unskilled labor by increasing its relative productivity and therefore its relative demand. Particularly, the theory deals with the changes that have occurred with the advancements in ICTs (Violante, 2004; Siegel, 1999). This bias occurs when the implementation of new technology increases for workers whose skills are complementary to technology. 
This bias is reflected mainly in wages; in the case of an increase in skill level, the ratio of wages of skilled labor rises more than the unskilled work force.

SBTC also claims that if the rate of technical change is low, there is little chance that any particular set of skills will become obsolete. But, if the rate is high, the effects of the change will be more detrimental over the skills.

As it is understood "skill" is a crucial aspect of the production process fo the firms. New technologies create many opportunities for workers in terms of training, increasing responsibilities or creating new jobs all of which definitely affect the skill composition of the worker. But, is this also valid for young apprentices in the small firms? In other words, how do the young workers deal with the technological and organizational developments in their firms? The research aimed to find an answer with a field research made in furniture production region located in Ankara.

\section{THE RESEARCH SITE AND THE SAMPLE}

As stated before this article aims at studying the employment impact of the technological changes on low skilled work force in general and on youth apprentices in particular. These innovative changes may either be realized in the production process or in the organizational setup of the firm. Furniture sector is the case for the research.

After the 1980s, the furniture sector is one of the fastest growing sectors in the country during the implementation of the export-led growth policies while the economy was endeavoring to articulate with the global markets. The share of the furniture sector in Turkey was about 4 percent in the total manufacturing industry in the 2000s. In 2015, Turkey realized 1.9 Billion US Dollars of furniture exports (which is 953 million US Dollars in 2005) and ranked as the 25th among 106 exporting countries (OAIB, 2016; DOĞAKA, 2014). These figures indicate that Turkey has an important place and has become a growingly powerful actor in the world's furniture market. 
The Siteler cluster of the capital city of Ankara/ Turkey is taken as the research site. Siteler is one of the most important production centers of furniture in Turkey. It is the second biggest site (the first site is Modoko located in Istanbul) in which almost 30.000 enterprises currently operate. The article deals only with the micro and small sized enterprises (MSEs) because according to statistics, the rate of MSEs in furniture sector is more than $90 \%$ and the number of employed people per firm is 6.9 (TUIK, 2003; SGK, 2012). Besides the micro and small sized firms are "assumed" to have more problems in adjusting themselves to the technological and organizational changes vis-à-vis large companies. Because, they are are still operating via traditional ways; that is to say, the technical capacity of the firms are extremely limited; accordingly, low skilled work force is employed. Due to time and social limitations, the interviews were conducted in 100 furniture enterprises. All interviews were carried out face to face, and for all of them, an appointment was arranged beforehand.

The research used here are the "quota" and the "snowball" sampling methods; which are also known as network or chain referral method (Blaikie, 2000). As there are more than ten thousand enterprises in Siteler (notes of an interview), the main sample of the research is gigantic and it is obvious that it is too hard to define the sample as the firms in Siteler as a whole. The basic criterion of choosing the sample is the enterprises which employ less than 50 people in total; these are specifically called as micro and small sized enterprises.

The other sample of the research was the young workers studying in the furniture departments of a vocational school located in Siteler region. There were about 150 students studying in the furniture and 
related departments of the same school. Including the young workers who are not enrolled in education sysytem in the firms, 171 respondents were taken into consideration.2

\section{RESULTS OF FIELD RESEARCH}

At first, the research made with companies are analyzed. They were asked why do they employ young apprentices, their problems; how do they deal with technological developments and changes in organizational structure right after the technological transfer. Besides, the workers were asked questions about their condition in the firms and impacts of the technological changes.

\subsection{Employment of Young Apprentices}

It should be pointed out that only 72 firms in the sample ( 72 percent) are employing youngsters. The total number of the young workers employed is 95 , thus, the average number of employed young workers per enterprise is 1,5 . It can be said that the use of youth employment does not seem like a dominant practice in this case, but it should be noted that the average employment rate in these firms (total number of workers in an enterprise) is 7,5.So, it can be concluded the incidence of youth labor is at a high level.

Almost all of the managers or masters of the firms expressed that having an apprentice or employing young workers in the furniture production is very important. That means such an additional work force is helpful in terms of doing simple tasks. Masters never do ordinary jobs, especially simple ones such as carrying the woods in the production area or carrying simple tools (screwdriver) or going to the grocery to buy

\footnotetext{
${ }^{2}$ It looks that two different research sites were used in the field. But it is not. The students are also workers in small firms. They have to spend half of the week in a firm and join the production process. So, the school was a proper source for the sample. But, the real reason is that it is believed in that they could compare the education and working life through their experiences. In spite of their views, the policy recommendations given in this article were established.
}

$\mathrm{SAD} / \mathrm{JSR}$

Cilt / Volume 21 Say1 / Number 1 
something or going to the bank to pay the electricity bill. All of these are the duties of the apprentices in the firms. Young workers have a social role in that sense.

Most of the young workers are actually not employed in the production, but in some auxiliary activities, in duties other than production. In 65 firms 86,3 percent are working elsewhere than production; they are employed for several duties in the enterprises; like an errand boy (The 65 firms mentioned here employs 95 apprentices in total). Their role is not at a high position or important like the masters in the firms but their position can be considered as an important component.

Furthermore, masters have a special role because the success of production process is intimately related to the capacity and ability of the masters. Masters should feel content and comfortable when they come to work. In other words, the managers should establish the necessary conditions to keep the job satisfaction of masters at a high level. In this regard, the young workers are not taken too much into consideration. Masters can demand more rights than the young workers because their role is much more crucial for the firm. Instead of firing the masters, all the managers prefer firing young workers firstly because the master can also take the secrets of the ex-firms with himself. In addition to this, there is another interesting underlying reason: the managers prefer not to fire masters because the master can easily create rumors and dispraise the ex-firm. 64,2 percent are registered officially and have social security protection. Therefore the rate of informal employment is 35,8 percent (29 young workers).

The main reason for employing young workers in the enterprise is to decrease the production cost (See Figure 1). As can be seen from that figure, 33 percent of the firms responded in that way. On the other hand, 31 percent of these firms employ young workers just to contribute to the vocational education system. 


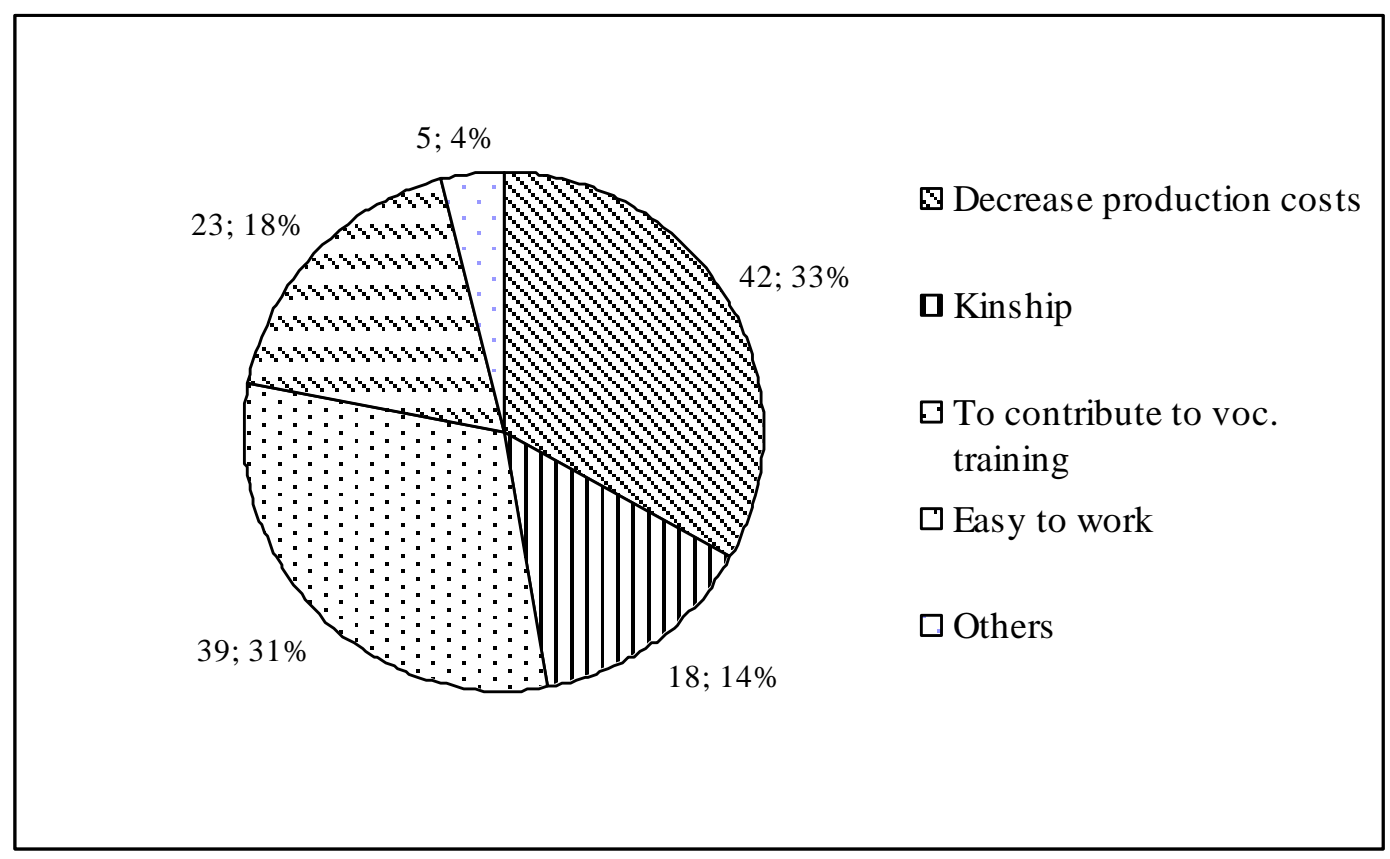

Figure 1. Reasons to Employ Young Workers

However, most of the firms' owners may not prefer to register students of vocational school because, if they do that, the youngster will need to go to school one day in a week which means loss of working hours. 23 firms told that it is easy to work with young workers. One of their reasons is that young workers are so naïve bodies that they can be easily managed. They do not argue with the master. They just listen and do whatever they are told.

\subsection{Problem of Skill in The Firms}

A very high proportion, i.e., 91 percent of the firms responded that they are in need of qualified or more skilled work force. They all complained about such shortcomings. They stated that the presence of a vocational school in the same region did not mean too much for them in terms of their demand for the qualified work force because the knowledge taught in the school seemed like a "shallow" knowledge as it was not compatible with the needs of the enterprises neither for production nor marketing. It is found that only 8 firms, less than nine percent, have no problem of the qualified work force. 
When the firms want to hire a worker, whether skilled or not, 84 percent of firms get some kind of help from other firms located in the same region. This means that in Siteler, which is the oldest furniture cluster in Turkey, a very strong social solidarity and close ties exist among the furniture producers. Probably the same socialized and friendly relations are practiced in other activities, such as granting loan credit without interest. In daily and simple relations, small furniture businesses are very keen on helping each other.

In Siteler, the workers frequently change firms. The turnover rate among these firms is very high. That means that they can easily leave one firm and be employed by another firm. The main reason behind such dynamism is the low wages and the desire of the workers for being registered to the social security system.

\subsection{Product and Process Innovation of The Firms}

63 percent of all firms started to produce new products during the last five years according to the findings. In other words, they are forced to undertake a process of "product differentiation" that they had never done before. This also shows that these furniture firms have tried to make changes in their policies and carry out innovations in order to get to good places in such a competitive market. New products always require new designs, new structuring in both production and organization levels, which all affect the labor relations within the firm itself.

Whether these firms have a marketing strategy or not, whether the technical capacity of the firms is sufficient in handling the changes in the product development schemes, and whether they can easily absorb these changes or not, are all crucial points that should be given special emphasis. All these points affect the employment relations within the firm.

\subsection{Technology Transfer}

31 percent of these firms implemented new production processes in the last five years (See Figure 2). But, the majority of the firms (62 percent of the firms) chose not to make changes in their production processes although they started to produce new goods. These figures show how low the technological level of 
furniture production remains or how the pace of technical changes is slow especially in the small-sized enterprises. More than half of the managers, particularly the young ones have planned to make some technological changes but their old-aged partners or their fathers were not flexible on this issue. It must be said that although old age entrepreneurs may be more conservative, reluctance for innovation is common in almost all small businesses. Somehow, the existing market share seems enough for the elderly.

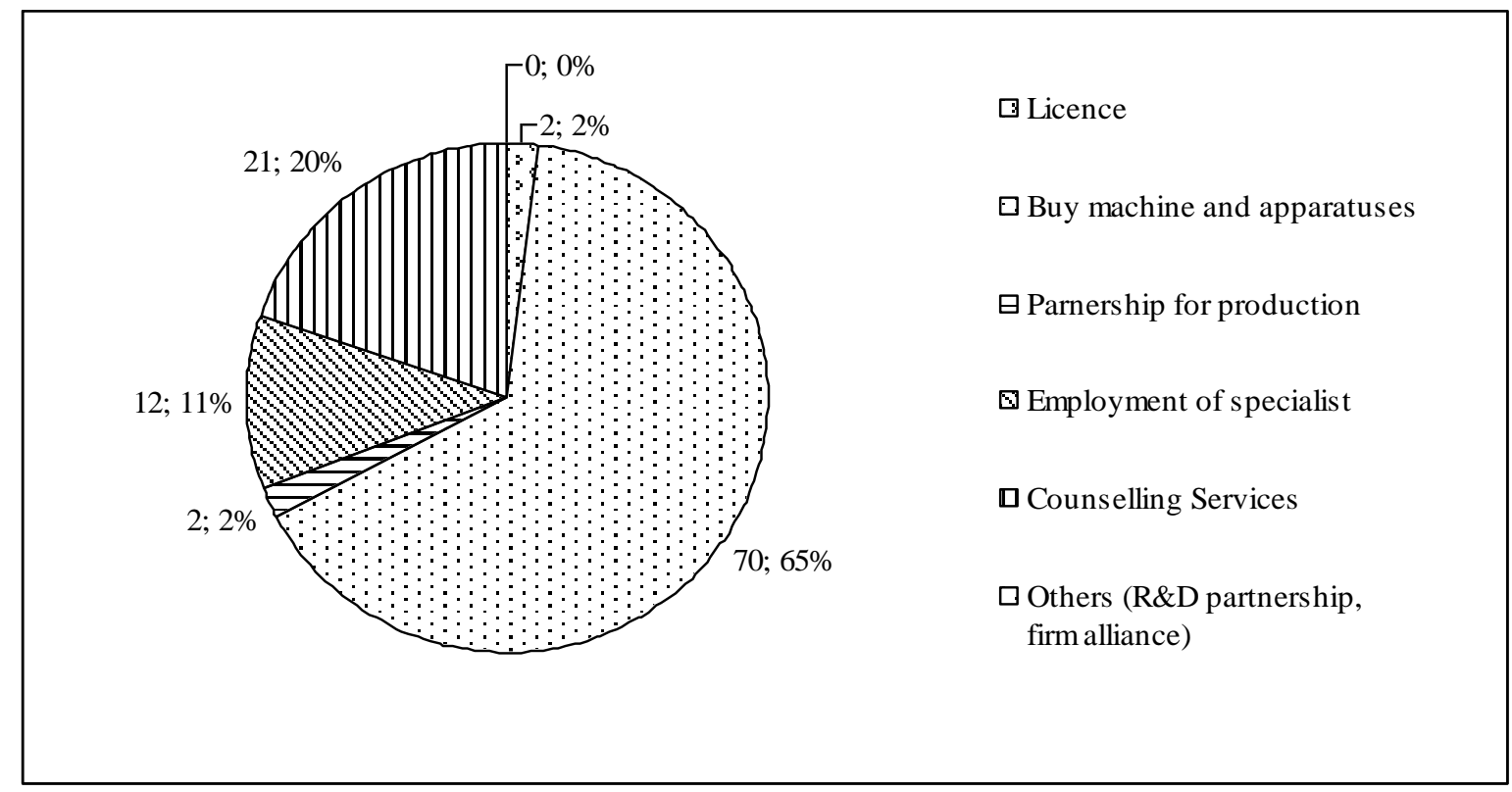

Figure 2. Types of technology transfer

On the other hand, the young managers, most of them being the sons or other close relatives, are struggling for technological improvements. This is what can be called the "gender gap" and it is an important social issue for the small businesses. About one-third of the firms in this research have tried to increase their technical and knowledge capacity in some sense. But, it is obvious that they are not successful in all subbranches of the sector; because firms are lacking the necessary knowledge pool concerning the ways of handling with those changes. The firms have given more emphasis to provide flexible production capacities but they are not very much aware of possible consequences of these changes, e.g., they are not very keen 
on studying the technical development in the furniture production. Although they have a large knowledge accumulation coming from the so-called "learning by doing" process; but they do not try to develop a production process that is special for the Siteler cluster.

The second biggest way of technology transfer for these firms is via counseling services. This shows that these firms are very much in need of knowledge about production, design, and marketing. This indicates the necessity of a knowledge pool in the region. Unlike the very strong solidarity in other areas, the firms do not prefer to share their knowledge about production and marketing among themselves.

The employment of skilled workforce is a critical element for the well-functioning of firms. It is mentioned that especially skilled workers are needed for the design. Most of the managers do the designs by themselves and they just learn it while working. The need for new designs is totally a result of changing customer demands and searching of new markets around the world; which is the general result of neoliberal transformations in the world economy. Solving the problem of skilled work force should be one of the main policy targets of the government.

Especially vocational training, and the student or graduated working young workers should be the main actors in supplying the skilled work force in the long run. Thereby, the social role of young workers could be improved. Such kind of policy will also improve the physical and mental development of the young workers that may be hampered during the heavy workloads. More skill will better prepare the young workers for the future and increase their position in the society. Vocational schools can act as the source of basic knowledge and, networks among the firms, young workers, and teachers should definitely be established.

More importantly, the close relation of technology transfer and its impacts on the change in the number of young workers is also examined. That is to say, it was tried to find out whether the technology transfer 
increases or decreases the number of young workers in these firms. According to the analyzes, 78 percent of firms, did make at least one type of technology transfer in the last five years and in 93 percent of these firms, there is a decrease in the number of employed young workers.

More interestingly, 95,8 percent of these firms are also in need of skilled work force in their firms. They complain about the lack of skilled work force in their firms and their region. This is quite a controversial issue since there is a decrease in the number work force but there is a need for the skilled work force. This totally shows the mismatch among the needs and the sources. The firms, the government, and even the workers do not know how to use the existing sources productively. This also shows that the ICT adoption in the firms does not solve every problem if it cannot be used properly. For that reason, knowledge, and ability to use it become the main tools for the social and economic development in the last decades.

As it understood, there is no single factor explaining of any change. Like a chain reaction, there may be a deep impact of technological developments. The spillover effect of large companies may have a positive impact in that sense. The managers of small firms can learn much if they can monitor them properly. This does not mean stealing the ideas. This means working hard and absorbing whatever is going on around their firms.

\subsection{Changes in Organizational Structure}

It is important to find out what happened to the organizational structure of the firms right after the technology transfer. Almost 27 percent of the firms also implemented organizational changes within the firm in the last five years. Whereas, 73,3 percent of them, did not make any change. These statistics show that the firms, in terms of organizational structure, are not so eager for making changes as they did for their production processes and are conservative in that sense. Somehow, due to the shrinkage in their market share, they have convinced themselves that they can handle with the existing market relations by themselves. 
Small firms have started to lose their local, national and international market shares since the 1990s. The introduction of factory production system and highly automated production facilities replaced the strength of traditional production system and has started to dominate the market. This can also be deduced also from the response where 57 percent of these firms felt that these changes did not have a considerable positive impact on their businesses. The growing competition in the market is one of the main reasons behind this but the efficient use of existing technology and marketing strategies should be taken into consideration as a major cause.

\subsection{The Use of Technology and Young Apprentices}

In this section, the young workers were asked some questions about using simple machines and more complex machines which contain advanced technological aspects. 59 percent can use high-tech machines under the control of a master or vice masters. 40 percent of them are never allowed to use such kind of machines. Out of 171 young workers, 75 percent of them are allowed to use simple machinery in work places. However, they are not allowed to use complex machines in the production processes.

In addition to that, in terms of technological machinery, interesting figures has come out: out of over 170 young workers, only 71 young workers ( 42 percent) are allowed to use such machinery whereas 31 percent of young workers can never use the technological machinery in the firms. 20 young workers have just started to use them but they were previously not allowed. 26 young workers which make 15 percent can seldom use the machines. The main reason of the prohibition about the machines is concerning the skill and knowledge level of the young workers. Almost all masters answered the question about the reason of such prohibition as: "they do not have the necessary knowledge" or "they may break it because they do not know how to control it" or "Using the machine is risky for their health". The risk of accident has always been a threat to these firms. Some of the young workers added also that the masters do not trust them in using the 
technical apparatuses. More interestingly, most young workers complain about the managers because they are not willing to educate them about the use of these machinery.

These figures definitely show the existence of a technological bias against the young workers. They are not allowed to use the machinery and they are often employed in easier tasks at production and other duties. In this regard, the young workers were also asked what happened when a change occurred such as the employment of new work force or the implementation new technological machinery. 34.3 percent of them replied that there their role had changed and they were employed in simpler tasks in the work places. The 65.7 percent of the young workers did not experience such a change because the adult workers were mostly engaged in important roles in the production process where the young workers were never as apprentices so their role did not change whatsoever. These figures definitely demonstrate that the deskilling impact of technology is very widespread in the small enterprises of the furniture sector.

But on the other hand, there is no clear evidence about whether working young workers lose their jobs due to the technological implementation or organizational restructuring processes. It is understood that, the manager employs skilled workers whenever necessary. It means that instead of educating the available apprentices there, the managers often prefer to employ somebody else for the job. This kind of bias against young workers is widespread in the region. The apprentices are very important for all firms but their roles are often neglected at many important duties like production or design. The only way of overcoming such kind of a bias is to increase the skill level of young workers but most of the managers expressed that they are not so keen on teaching everything to the young workers because when young workers learn something, they can demand more wage and leave the firm easily when they cannot get what they want. This kind of dilemma is so hard to solve since the young workers are really in need of skill as they grow up to earn more and to attain a higher status. However with this type of "teaching" process, former young workers will 
become masters and establish their own production units, thus, it is thought that firms may lose their market shares to the new competitors and their production capacity may decrease.

To have a decent job and thus a good life in the future, the young generation working in this sector should not be alienated from the production process. They have to be forced to increase their skill level. They have to learn how to market the products and the products /materials themselves. They have to learn to use the machines. That is to say, they have to become friendly with the technology. Otherwise, such kind of bias cannot be removed. They have to be pulled into the process, not being pushed out of it. Being pushed creates obviously a deskilling process for the young worker which definitely implies a major problem for him/her.

\subsection{The Conditions of Young Workers in The Firm}

In this section, some questions about the young workers' working period, wage, and social rights will be discussed. When the working period is considered, 88 percent of 171 interviewed workers are full-time. When weekly work is taken into account, about 62 percent of young workers are working six days a week. Only 56 young workers are working five days. Relatively a very small amount, less than four percent, corresponding to 6 young workers are working all seven days of the week. However, daily duration of work is rather long. In all categories, young workers are working on the average around 8-9 hours per day. All these figures show that the working young workers are often exposed to long working hours which is a kind of worst form of child labor (ILO, 2004).

51 percent of young workers are given monthly wages and 42 percent of them are given weekly wages. Most of the young workers are taking their wages by cash. The wage level is mainly determined by the owners of the firms. Young workers cannot argue about the amount of the wage. This is obviously related to the low level of the social role of young workers in that region. As it is in almost every job, the young workers do not have power in terms of arguing for the rights. Their parents or the masters are the decisionmakers in this regard. 
Many of them believe that they get a low wage. This also shows the age-bias behavior on the wages in the sector. That means the young workers have always earned low wages as compared to the other workers. The main criteria in the determination of wages are their ages, not their skill level. In order to earn more, they should spend more time in the firm. The family workers cannot get even any regular wage from their managers. This may be attributed to the notion of unpaid family worker and it is obvious that such kind of familial relation may not have an official basis in which all the regulations, rules and rights are clearly defined. Within the total 171 working young workers, 68 percent are often employed in duties that are different from their ordinary or assigned work. These are often simple tasks that do not require a skill profile.

Another question was about the education process in the firm: 147 young workers who make 86 percent cannot get a special education in the firm. Most of the managers or masters prefer to train the young workers while they are working. This shows that they do not want to spend too much time for special education facilities and do not want to loose time from production. These figures also show the bias against the young workers in the firm.

One of the interesting results of this study is that most of the young workers have a social security record. These numbers look high because most of the young workers are students in vocational schools thus they have to be registered at the firm. Otherwise, that is without social security, they are not accepted to schools. 86 percent of workers have a social security record. Only 24 young workers who make 14 percent are unregistered. The unofficial employment practices have very negative effects on the work processes in the furniture sector in Siteler. Starting with very low levels of wage; the high amount of worst forms of labor, such as working very long hours or under unhealthy conditions are the main characteristics of the jobs. These negative aspects or factors decrease the desire of people to work in that sector. This situation also explains the high rate of work place changes; (turnover rate) among the youth. The workers have begun to 
demand more rights and registration in the Siteler cluster. Instead of working under unhealthy conditions and unofficially, they preferred to move to the service sector.

Furthermore, only 47 young workers are aware of their social rights whereas the rest do not know anything as to what their social rights are. Theoretically, as mentioned before, certain forms of work processes may affect the health conditions of young workers. These conditions may cause severe damages both physically and mentally (ILO, 2004). Around 20 percent of young workers in the sample have been injured previously.

It should be admitted that work environments in the furniture sector need to be maintained in a safe and orderly fashion. Failure to take adequate preventative measures, such as installing properly grounded electrical systems to prevent the risk of electrical shock, etc. may lead to serious work accidents or occupational diseases that could have been easily avoided otherwise. Still, other risks may arise from the failure to comply with the employment regulations, such as requiring employees to work long work weeks or failing to provide them with regular rest breaks (MLSS, 2007: 54).

\subsection{Changes in The Condition of The Labor Force}

One of the main questions of the interview was about the quantitative change of labor force in the firms. For 91 percent of the firms, the number of workers has decreased in the last five years. Only 9 firms expressed that there is no change or an increase has been experienced. Sometimes changes are seasonal. The numbers show that all the firms have experienced important transformations both socially and economically in the last years. On one hand, the fast technical changes and the neoliberal economic atmosphere totally destroyed the existing market relations. On the other hand, due to these changes, many firms, especially small ones became unable to respond to these changes properly and lost their market shares and economic power.

The main reason behind that change is the lack of demand, or with their words, "absence of business". Most of the managers expressed that if there is nothing to do, there is no need to employ more people.

$\mathrm{SAD} / \mathrm{JSR}$

Cilt / Volume 21 Say1 / Number 1 
One of the interesting points is that the master who can not earn more or demand a social security registration is the first group of workers who leave the firm. Most people have realized the importance of the social security registration. Especially for the masters, it is easy to leave the firm that does not give what he wants. Because he is a master, he has the necessary skill and knowledge level to find another job. He also has the option to start his own business. He has some options in that sense.

In addition to that, most of the masters who leave the firm might also decide to change sector. That means, they could decide to work in the service sector or machinery sector. The first motive is the social security registration; the second one is the money for living. Such kind of situation shows that the furniture sector, especially for small firms, has lost their charm as a working place. It does not attract people to work since these firms cannot earn more and so they cannot give enough wage and social rights to their workers.

Working youngsters are not as lucky as the masters. When business conditions do worsen they are the first group of workers to be fired. Even in the case of hiring another worker, specially who has a special skill like a master; the first laborers who have to quit the job are the young workers. About 95 percent of the firms expressed that they fired many workers since they became unnecessary for the firm after hiring other people or buying machinery. Besides, the managers also preferred to send young workers in the first place. The reason is that it is much easy to fire young workers since they cause less trouble. They do not prefer to send adults or masters because these people may disseminate gossip or confidential knowledge about the inability of the firms in case of being fired. It is understood that the socially constructed role of young workers looks a little underestimated by the adults. Another question was whether the number of young workers has increased or decreased. It is found out that 93 percent of the firms have experienced a decrease in the number of working youngsters. Those firms have somehow had to send the young workers to other places. As they expressed, most of the young workers who left the firm tried to work in another firm located in Siteler. In that sense, the majority of these young workers became "labor of reserve army" (Marx, 1978) 
for the firms in the region. On the other hand, few of them decided to the changed sector and worked in the service sectors, like restaurants or cafes... etc.

\section{RECOMMENDATIONS}

When a change happens in small firms' production process, the young apprentices is affected negatively. Because, they do not know the ways how to handle with changes. It is believed that such kind of problem arises because of the inconvenience between the vocational training system and the requirements of firms in the market. For that reason, the missing link between these actors should be re-established. This is the underlying logic of this section.

\subsection{A Policy Model Regarding Youth Employment: Participatory Education}

In the vocational training model, there are three main elements which have to operate in a coordinated and efficient manner for obtaining positive results. The first element is obviously the young apprentice. The second but definitely not secondary element is the teacher/instructor who will function as the pillar of the system for this purpose. However, it should be noted that, since technology is rapidly changing, the teacher him/herself must also have a continuous learning process. The third element is the private business; namely the managers of the firms. Of course, for a successful training system, these three components are necessary but not sufficient. There must be qualitative elements from the organizational and institutional standpoints that need to be fulfilled; a dynamic/continuous coordination between skill formation and technological developments, i.e., a life-long learning process must be followed. The lack or an inferior role of one of these actors will definitely bring the collapse of the system.

As a first step, the governmental bodies and the representatives of private businesses should come together and try to establish a new curriculum for the vocational training. This curriculum should undeniably be established according to the demands or needs of the private businesses which are a natural outcome of their existing technological levels, marketing strategies, and managerial aspects. The young students should 
be donated with all kinds of necessary knowledge and obtain the required training practices and experiments when they graduate from school. In that way, the managers will come to believe that these youngsters are sufficiently skilled and have enough knowledge.

Another role of the private business is the managers or rather the "masters" of the profession participating in the classes. The young apprentice should learn the necessary knowledge or should acquire the necessary technological practice from the first actor of the system, being masters/managers, along with the formal actor, which is the teacher. In that sense, the major contribution should be provided by the business associations in the region by undertaking a greater role during the process. The second part of the system is the practical work applications. That means it is a must for the knowledge to be applied directly at the right place; namely in the firms.

In the current system, the students in the school spend five days of their working week in the firms and one day in schools. But, none of the managers place a special emphasis on the content of the lessons because they believe that the lessons are incompatible with their plans and visions. For this reason, the participatory education system will improve the trust of the managers to the vocational system.

\subsection{A Crucial Support Mechanism: Research and Development Centers}

Obviously, the furniture sector has crucial problems that are peculiar to it. As it was mentioned in the results of the field work, one of the main problems of the small firms of the Siteler region is the low technological capacity in the world of big corporations, both domestic and foreign. Besides, the very low level of financial strength lacking capital make firms unable to make necessary technological investments. Nevertheless, it should be admitted that the low vision and low level of knowledge of firms' managers are also very effective in that sense. Most of them are aware or have some feeling about what will be happening in the furniture market. However, they do not know how they can benefit from existing and/or changing conditions. They are really in need of assistance to work productively and thus to be abreast of the improvements in the 
global furniture market. In that sense, it should be added that, along with the financial problems, the lack of necessary human capital and the lack of professional advises are the main reasons that hamper the success of technical adoption.

Furthermore, the furniture firms have also faced problems in using new machines or making organizational changes in full capacity. They cannot utilize the full capacity of new machines because of organizational shortcomings. As it is understood from the research, the rate of capacity utilization of furniture enterprises remains at very low levels -around 75 percent of the average-. In order to solve such problems, some special centers can be established in the region, which would provide help to all firms on any subject related to furniture production. For example, these centers can help firms in making design according to the latest fashion or according to latest industrial techniques. Moreover, these centers may support the firms in marketing procedures (teaching new techniques in brand management), finding new customers across the globe or teaching them about the most productive way to use the furniture materials.

That is to say, along with skilled work force, the firms are really in need of knowledge in all aspects of furniture production; i.e. from material knowledge to fashionable design or from marketing to new production techniques. In every step, they may be faced with some problems. The R\&D Centers which will be established in a coordinated manner that is to say with the participation of private, public parties as well as, if possible, with the labor unions may serve for better for all firms.

Another important step for Siteler firms may be undertaking a specialization process in the production processes. In other words, there are thousands of firms, either small or medium sized, operating in the region which is trying to manufacture "every kind" of furniture. But, this high number is not a result of higher profit rates. In fact, they remain weak in competition and their market share remains very low. For that reason, the small firms have to come together and make collaborations in every aspect of the whole furniture production, including a supply of inputs, design, marketing and servicing processes. It may be a good idea 
for them to specialize in a specific type of furniture. If they come together, they would be more powerful against big corporations and remain competitive in the market. Otherwise, in a fast globalizing furniture market, their future does not seem bright. In that sense, the main role should be taken by business associations located in the region. 


\section{CONCLUSION}

It is clear that the adoption of new technology into both production and managerial processes for small sized enterprises have positive and negative outcomes. The debate in this article focused on possible bias of technological developments over skill composition of the workers. Technology implies increases in the demand of skilled labor for successful adoption. This condition can be seen better in furniture sector which owns a strong dilemma: the old school production process vs new technological developments. The firms in Siteler have considerably felt the polarization of romanticism of the old and traditional production processes and the market forced requirements of the new technological improvements. This is why furniture sector was chosen as a case.

It is found out that the technological changes implemented by small firms, which reflected the managerial decision process, have definitely affected the status and working conditions of youngsters in a negative manner. Most of them are employed in very simple duties but with detrimental impacts on their physical and mental capacities. Some of them even lost their jobs in previous years just because of such applications of new machinery and equipment.

Another interesting outcome of the field work is that the role/status of the youth has always tended to be diminished both in the firm and in the region. For example, it is found out that the permission to use machinery is an important issue in the process of employing young workers. Many firms have strong rules and regulations, although not written, on this subject. It is also understood that the main reasons for the prohibition of the use of machines are the low or very limited skill and knowledge levels of the young workers.

It can be stated that the ICT adoption includes not only improvements in physical assets of firms but also improvements in organizational structure and social relations. Since change is a continuous process, there is no optimum solution or exemplary for the best organizational structure. As the production and marketing 
technologies create environmental, behavioral and cultural changes, so should the organization. Both the manager and the employees need to continuously acquire new skills and knowledge and develop new cultural and behavioral norms within their organizations. This shows the social factors of technological advancements which affect negatively the working processes of young apprentices.

As it is found out from the field work, almost all of the young apprentices are very much in need of the technology literacy. They have to learn how to get the best out of the complex technological machinery. Two crucial recommendations were made in order to cope with this problem: Better coordination among three main actors (private sector, young workers and governmental institutions) will create better vocational policies. Besides, a training center will definitely improve the quality of skill composition of young apprentices. What is needed is a continuous education and training within a dynamic set up, i.e., according to the changing aspects of the technology side. Those initiatives will definitely increase not only the skills of the employed youth but also their status in the firm as well. Even more importantly, being technologically literate, makes the young workers believe in themselves.

This research has also endeavored to bridge the knowledge gaps which exist on various aspects of youth employment, especially in the furniture sector of a specific location in Turkey. The focus of the research has been to explore the less known issues such technological development and the employment of young apprentices. Although there is a body of literature, data and surveys on the youth, there are still considerable gaps in understanding the variety of forms and conditions in which youth are employed. 


\section{ÖZET}

Teknolojik değişimler ve 1980lerle beraber ortaya çıkan neo-liberal politikalar dünya pazarlarında ve bu bağlamda firma yapılarında büyük değişimlere yol açtılar. Yeni işletim ve üretim yapıları ortaya çıtı. Bu da emek süreçlerinde ve ilişkilerinde değişimlere neden oldu.

Bu araştırma küçük ve orta ölçekli firmalarda üretim süreçlerinde gerçekleştirilen teknolojik değişimlerin ve firma organizasyon yapısında oluşan değişimlerin firmada istihdam edilen genç işçiler üzerindeki etkilerini incelemeyi amaçlamaktadır. Yani sosyo-teknik süreçlerin genç çalışanların üzerindeki etkilerine bakılmak istenmektedir.

Türkiye mobilya sektörün ve o sektörde çalışan genç işçiler tezin örneklemini oluşturmaktadırlar. Alan çalışması, Türkiye mobilya sanayii ve Ankara için çok büyük önemi olan Siteler mobilya sanayinde gerçekleştirilmiştir.

Temel sorunsal ise: “Teknolojik değişimlerin küçük ve orta ölçekli firmaları nasıl etkilemiş ve bunlardan esas olarak genç işçiler nasıl etkilenmiştir?” olarak oluşturulmuştur. Bu bağlamda “vasıf” kavramı tezin temel tartışma konusu olarak ele alınmıştır.

Yeni teknolojiler, firmaların yeni gelişen pazar ilişkilerinde daha rekabetçi olabilmeleri ve yaşam savaşını kazanabilmeleri için yapılmaktadır. Ama bu yatırımların esas başırısı firmanın kendi kaynaklarına ve özellikle de insan kaynağına bağlıdır. Vasıflı işçilerin varlığı hem değişimi kolaylaştırmakta hem de verimliliği artırmaktadır.

Tezin hipotezi şöyle oluşturulmuştur: Globalleşme süreci ve bunun ekonomik göstergesi olan neo-liberal politikalar küçük ve orta ölçekli firmalarda da büyük değişimlere yol açmışlardır. Özellikle üretim süreçlerinde ve firma yapısında yapılan bu değişimler istihdam edilen genç işçiler üzerinde vasıfsızlaştırma ya da üretim süreçlerinden uzaklaştırılma gibi olumsuz etkilere neden olmaktadılar. 
Uluslararası firmaların girdiği ulusal pazarlara yeni bilgi birikimi ve teknoloji getirerek o pazarda faaliyet gösteren diğer firmaları da değişime zorlamaya başlamışlardır. Pazar payları düşen firmalar varolabilmek için teknolojik ve firma yapılarında değişime gitmek durumunda kalmışlardır.

Bilginin en önemli ekonoik gelişim silahı olduğu bir dönemde yükssek vasıflı çalışanların önemi düşük vasıflı işçiler karşısında bir adım öne çıkmaktadır. Bu bağlamda teknolojik değişimlerin yüksek vasıflı işçileri daha önemli hale getirdiği ve diğerlerin arka plana ittiği söylenebilir. Bu bağlamda yeni dönem kapitalist üretim ilişkilerinde bir kutuplaşma oluşmaktadır. Yeni üretim süreçleri ve esmek firma yapıları kendilerine uyum gösterebilen işçilere ihtiyaç duymaktadır. Yetersiz vasıfta olan çalışanların önemli azalmaktadir.

Ortaya çıkan önemli bulgular şöyle sıralanabilir:

- Türkiye mobilya sanayii son yıllarda önemli atılımlar yaparak dünya pazarlarında yer edinmeye başlamıştır. Büyül ölçekli üretim yapan firmaların sayısı artmakta ve Türkiye pazarına giren yabancı firma sayısında da artış yaşanmaktadır.

- Bu değişimler küçük ve orta ölçekli firmalar üzerinde yaşam savaşı sayılabilecek derece de bir etki yaratmıştır. $\mathrm{Bu}$ firmalar pazarda var olabilme savaşı vermektedirler. Bunun için de üretim süreçlerinde ve firma yapılarında değişimler gerçekleştirmektedirler.

- Küçük firmalarda çalışan gençler, tenolojik değişimler karşısında büyük sorunlarla karşılaşmaktadırlar. Özellikle firma sahipleri yeni makinaların kullanımında gençlere hiç görev vermeyerek, üretim süreçlerinden uzaklaşmaktalar ve önem işlerde çalıştırmktadırlar. Bu tip uyguamalar gençlerin sosyal konumlarını önemsizleştirmekte ve iyice onları süreç dışına itmektedirler. 
- Oysaki işsizliğin giderilmesi için yapılabilecek en önemli iş gençlerin sürece dahil edilerek vasıf kazanamalarına yardımcı olmaktır. Ama bu bağlamda da çıraklık okullarındaki kalitenin artırılarak firmaları bu konudaki taleplerine cevap verebilecek bir işçi profili yaratılması gerekmektedir.

- Bu bağlamda konunun muhattapları olan özel sektör temsilcilerinin, hükümet yetkililerinin ve hatta çalışanlarında eğitim politikalarının oluşturulması sürecine dahil edilmeleri gerekmektedir. $\mathrm{Bu}$ sayede ortaya herkese uygun bir sistem çıkarılabilinir. 


\section{REFERENCES}

Alam, S.S., \& Noor, M.K. M. (2009). ICT Adoption in Small and Medium Enterprises: An Empirical Evidence of Service Sectors in Malaysia. International Journal of Business and Management, 4(2), 112-125. http://dx.doi.org/10.5539/ijbm.v4n2p112.

Attewel, P. (1990). What is Skill?. Work and Occupations. 17:422-428. https://doi.org/10.1177/0730888490017004003

Bayo-Moriones, A.\& Lera-Lopez, F. (2007). A Firm-Level Analysis of Determinants of ICT Adoption in Spain.Technovatiom Vol 27, Issues 6-7, 352-366.

Bell, D. (1973). The Coming of Post-Industrial Society: A Venture in Social Forecasting. New York: Basic Books.

Blaikie, N. (2000). Designing Social Research. UK: Polity Press.

Braverman, Harry. 1974. Labor and Monopoly Capital: The Degradation of Work in the Twentieth Century. London: Monthly Review Press.

Doğu Akdeniz Kalkınam Ajansı- DOĞAKA. (2014). Mobilyacılık Sektör Raporu. Access Date: 11.04.2017. http://www.dogaka.gov.tr/Icerik/Dosya/www.dogaka.gov.tr 528 GD1X14ED Mobilyacilik$\underline{\text { Sektor-Raporu-2014.pdf }}$

Foray, D. and Lundvall, B.A. (1996). The Knowledge-Based Economy: From the Economics of Knowledge to the Learning Economy. D.Neef, A.Siesfeld, J.Cefola (Ed.). The Economic Impact of Knowledge içinde (s. 115-122). Boston: Butterworth-Heinemann.

Glyn, A., (2006). Capitalism Unleashed: Finance, Globalization, and Welfare. Oxford, Oxford University Press.

Harvey, D. (1989). The Condition of Post Modernity. Oxford: Basil Blackwell.

Hietala, K. (2005). Human Capital: A Sub-Report of General Framework for Long Term Social Impact Evaluation of an Employment Strategy. Access Date: 24.07.2015 
http://ec.europa.eu/employment_social/incentive_measures/studies/soc_imp_ees_sub_rep3_en.pd $\mathrm{f}$

Higon, D.A. (2011). The impact of ICT on innovation activities: evidence for UK SMEs. International Small Business Journal, 30(6), 684-699.

International Labour Organization (ILO). (2004). Child Labor: A Textbook for University Students. Geneva: ILO Pub.

Lipietz, A. (1997). The Post-Fordist World: Labor Relations, International Hierarchy and Global Ecology. Review of International Political Economy. Spring: 1-41. https://doi.org/10.1080/096922997347841

MacGregor, R.C. and Bunker, D.J. (1996). The Effect of Priorities Introduced During Computer Acquisition on Continuing Success with It in Small Business Environments. Proceedings of the Information Resource Management Association International Conference, Washington, 271-277. New York: IGI Global.

Manning, A. (2004). We Can Work it Out: The Impact of Technological Change on the Demand for LowSkill Workers. Scottish Journal of Political Economy, Vol. 51, No. 5, pp. 581-608. https://doi.org/10.1111/j.0036-9292.2004.00322.x.

Manochehri, N.N., Al-Esmail, R., \& Ashrafi, R. (2012). Examining the Impact of Information and Communication Technologies (ICT) on Enterprise Practices: A Preliminary Perspective from Qatar. The Electronic Journal on Information Systems in Developing Countries (EJISDC), 51(3), 1-16. Access Date: 03.04.2016. https://squ.pure.elsevier.com/en/publications/examining-theimpact-of-information-and-communication-technologie.

Marx, K. (1978). Capital Vol. 1. Moscow: Progress Publishers.

Matei, A., \& Savulescu, C. (2012). Empirical Analysis of ICT, Economic Growth and Competitiveness in the EU. The International Conference on. ICT Management (ICTM 2012). Wroclow, Poland. Access date: 03.04.2016. https://ssrn.com/abstract=2173340.

Ministry of Labour and Social Security (MLSS). (2007). Project Report on Eliminiating Worst Forms of Child Labour in Furniture Sector. Ankara: MLSS Pub. 
Orta Anadolu İhracatçı Birliği-OAİB. (2016). Mobilya Sektör Raporu. Ankara: OAİB Yay.

Peterson, T. O. and Van Fleet, D. D. (2004). The Ongoing Legacy of R.L. Katz: An Updated Typology of Management Skills, Management Decision, Vol. 42 Issue: 10, pp.1297-1308. https://doi.org/10.1108/00251740410568980.

Piore, M. and Sabel, C. (1984). The Second Industrial Divide: Possibilities for Prosperity. New York: Basic Books.

Piva, M. and Vivarelli, M. (2002). The Skill Bias. International Review of Applied Economics, Vol. 16, No. 3, 347-357. https://doi.org/10.1080/02692170210136163.

Reynolds, W., Savage, W. and Williams, A. (1994). Your Own Business: A Practical Guide to Success. ITP.

Rifkin, J. (1996). The End of Work: The Decline of the Global Labor Force and the Dawn of the PostMarket Era. New York: G.P. Putnam's Sons Pub.

Rigby, M. and Sanchis, E. (2006). The Concept of Skill and its Social Construction. The European Journal of Vocational Training 37: 22-33. Access date: 12.06.2015. https://core.ac.uk/download/pdf/17733181.pdf

Ritchie, B. and Brinley, C. (2005). ICT Adoption by SMEs: Implications for Relationships and Management, New Technology. Work and Employment 20, No. 3: 205-217. https://doi.org/10.1111/j.1468-005X.2005.00154.X

Robinson, W. (2004). A Theory of Global Capitalism. London: The Johns Hopkins University Press.

Sosyal Güvenlik Kurumu (SGK). (2012). Ístihdam Verileri ve Iş Yeri Sayısı. Ankara: Sosyal Güvenlik Kurumu.

Siegel, D. (1999). Skill- Biased Technical Change. London: W.E. Upjohn Institute Pub.

Spectrum (1997). Moving into the Information Society. London: HMSO.

Stöhr, W. (1990). Global Challenge and Local Response: Initiatives for Economic Regeneration in Contemporary Europe. London: Mansell Publishing. 
Traute, A., Gatautis, R. (2014). ICT Impact on SMEs Performance. Procedia-Social and Behavioral Sciencces, 110, 1218-1225. doi: 10.1016/j.sbspro.2013.12.968.

Türkiye İstatistik Kurumu - TÜİK (Turkish Statistics Institution). (2003). Genel Sanayi ve İsyerleri Sayımı 2002. (Census of General Industry and Business 2002), www.tuik.gov.tr (Access: March, 215)

Vallas, S.P. (1990). The Concept of Skill. Work and Occupations, 17: 379- 388. https://doi.org/10.1177/0730888490017004001.

Violante, G. (2004). Skill Biased Technical Change. Access: January, 2016. http://www.econ.nyu.edu/user/violante/Books/sbtc_january16.pdf.

Wood, S. (1989). The Transformation of Work: Skill, Flexibility and the Labor Process. London: Routledge Publications.

Zimbalist, A. (1979). Case Studies on the Labor Process. In P. Attewel (Ed.). Work and Occupations, 17. 422- 428.

Zuboff, S. (1988). In the Age of the Smart Machine: The Future of Work and Power. Oxford: Heinemann Professional Press. 